\title{
Rethinking flood risk communication
}

\author{
E. Rollason ${ }^{1}$ (D) L. J. Bracken' ${ }^{1}$ R. J. Hardy ${ }^{1}$ A. R. G. Large ${ }^{2}$
}

Received: 29 June 2017/ Accepted: 11 March 2018/Published online: 19 March 2018

(C) The Author(s) 2018

\begin{abstract}
Flooding is a serious hazard across Europe, with over 200 major floods documented in the last two decades. Over this period, flood management has evolved, with a greater responsibility now placed on at-risk communities to understand their risk and take protective action to develop flood resilience. Consequently, communicating flood risk has become an increasingly central part of developing flood resilience. However, research suggests that current risk communications have not resulted in the intended increase in awareness, or behavioural change. This paper explores how current risk communications are used by those at risk, what information users desire and how best this should be presented. We explore these questions through a multi-method participatory experiment, working together with a competency group of local participants in the town of Corbridge, Northumberland, the UK. Our research demonstrates that current risk communications fail to meet user needs for information in the period before a flood event, leaving users unsure of what will happen, or how best to respond. We show that participants want information on when and how a flooding may occur (flood dynamics), so that they can understand their risk and feel in control of their decisions on how to respond. We also present four prototypes which translate these information needs into new approaches to communicating flood risk. Developed by the research participants, these proposals meet their information needs, increase their flood literacy and develop their response capacity. The findings of the research have implications for how we design and develop future flood communications, but also for how we envisage the role of flood communications in developing resilience at a community level.
\end{abstract}

Electronic supplementary material The online version of this article (https://doi.org/10.1007/s11069-0183273-4) contains supplementary material, which is available to authorized users.

E. Rollason

e.d.rollason@durham.ac.uk

1 Science Laboratories, Department of Geography, Durham University, South Rd, Durham DH1 3LE, UK

2 School of Geography, Politics and Sociology, Newcastle University, Newcastle upon Tyne NE1 7RU, UK 
Keywords Flood risk · Resilience $\cdot$ Flood mapping $\cdot$ Communication · Participation

\section{Introduction}

Flooding is a major hazard throughout Europe (de Moel et al. 2009), with over 2.4 million properties potentially at risk in the UK alone (Environment Agency 2009). Over the last decade flood risk management (FRM) has evolved to develop and enhance community resilience to flooding, rather than controlling flood waters using engineering solutions (Van Alphen et al. 2009). Communication of flood risk information is a key element of FRM which aims to 'strengthen people's risk awareness and to motivate the population at risk to take preventive actions and to be prepared' (Hagemeier-Klose and Wagner 2009, p. 564). Communication of flood risk is a valuable way to link expertise and management undertaken by practitioners with the development of local-level resilience in an at risk community (de Moel et al. 2009; Butler and Pidgeon 2011).

Flood risk communication encompasses two phases: firstly, identifying areas at risk of flooding, and secondly, letting those at risk know when flooding is likely to occur. Both phases are crucial to helping those at risk prepare for, anticipate and act to lessen the consequences of flood events. This is a vital element of developing community resilience; flood impacts can be significant, extending beyond those whose homes are directly flooded, and for prolonged periods following a flooding event. For instance, research has demonstrated that flooding can result in increased morbidity (Milojevic et al. 2017), increase the occurrence of infectious diseases (Waite et al. 2017), and cause significant, long-term mental health impacts (Lamond et al. 2015) including depression, anxiety and post-traumatic stress disorder (Munro et al. 2017). As well as helping people take action to reduce the impact of floods on their homes and to evacuate areas of high flood hazard, flood risk communications have also been shown to have a significant impact on reducing longerterm impacts. For example, Munro et al. (2017) demonstrate that receiving timely warning prior to a flood was the only factor likely to limit the impact of flooding on mental health. Communicating flood risk prior to, and during flood events, is thus crucial to limiting flood impacts and ensuring well-being in at-risk communities.

This paper explores current flood risk communications and their effectiveness in promoting resilient behaviours, and introduces new ways in which information could be presented to increase action to limit flood impacts. This assessment focuses on the approaches adopted in Europe following the introduction of the European Union Floods Directive (EUFD) (European Parliament and the Council 2007), which has resulted in a unification of communication approaches between countries within the EU. We employ a case study in the UK, where we work with a community that have previous experiences of flooding to (1) examine existing approaches to flood communications, (2) explore how we can work with at risk participants to develop new ways of thinking about the content of flood risk communication, and (3) use participatory approaches to co-produce a series of prototypes for more effective flood risk communications.

Research in psychology has explored the way in which risk messages are translated into behaviour by those receiving them (for example, see Slovic et al. 1974; Fischhoff et al. 1993; Burns and Slovic 2012; Bubeck et al. 2012). However, in the translation of this research into risk communication practice, those at risk are often framed as needy, and reliant on experts to dictate what risk information is important and why (Willis et al. 2011). This means at risk communication users are often excluded from the processes of creating risk communications. By adopting participatory practices, and working together with those 
at risk, the research presented in this paper looks to circumvent this framing by allowing research participants to determine what information is important to them for understanding their risk and increasing their resilience.

\section{Current approaches to communications in flood risk management}

Across Europe, the 2007 EUFD established common standards for the preparation of flood hazard and flood risk maps (EXCIMAP 2007a). The UK provides a good example of these products, with the Environment Agency (EA) publishing a well-developed suite of different mapping types available online (de Moel et al. 2009), alongside an array of supporting communications (Table 1). These include communication of real-time river levels, and flood alerts and warnings intended to highlight the short-term potential for flooding.

The EA's prime purpose for flood risk communications is to encourage participation in local FRM and develop community resilience (Environment Agency 2011). EA research on resilience has previously focused on generating trusted, long-term relationships with atrisk communities (Twigger-Ross et al. 2011, 2014) (Table 1). As a result, communications have traditionally been supported by a network of local flood groups and wardens, tasked with working alongside the EA to prepare local communities for flooding (Gilissen et al. 2016). However, recent high-profile floods have caused a shift of focus towards infrastructure and property-based resilience programmes (McBain et al. 2010; Chatterton et al. 2010; Environment Agency 2011). As a result, community-based resilience has become somewhat of a secondary objective and the potential for risk communications as an enabler of resilience has taken on a much greater level of importance (Environment Agency 2010). However, the existing research suggests that current communications are having limited impact on driving risk awareness or resilient behaviours. O'Sullivan et al. (2012) examined the impact of flood risk communications across Europe and identified low levels of information penetration and personal preparedness, often accompanied by a high level of

Table 1 Flood risk communications approaches in England and Wales

Communications $\quad$ Description and purpose of the communications
approach

$\begin{aligned} & \text { Flood hazard and risk } \\ & \text { maps }\end{aligned}$
$\begin{gathered}\text { These online maps indicate areas of potential flood hazard and differentiate } \\ \text { high-, medium- and low-risk categories. Intended to raise awareness of the } \\ \text { risk of flooding of those living in at-risk areas } \\ \text { Common to the majority of countries in the EU (EXCIMAP 2007a, b; de Moel } \\ \text { et al. 2009) } \\ \text { Hydrographs of 'real-time' river levels monitored at river gauging stations } \\ \text { provided online. During flooding conditions these records are updated at } \\ \text { 15-min intervals. These hydrographs also display the level over which } \\ \text { flooding can be expected and the highest level ever recorded. Intended to } \\ \text { allow local people to monitor local river levels and decide when to take action } \\ \text { in response to potential flooding } \\ \text { A flood warning system is also implemented across England (Fielding et al. } \\ \text { 2007). Three alert levels are provided, the intention being that those at risk } \\ \text { should begin to monitor local river levels at the Flood Alert Stage and begin to } \\ \text { implement flood-resilient actions at a Flood Warning Stage. Intended to } \\ \text { instruct those at risk when to take action in response to a potential flood } \\ \text { (Flood Information }\end{gathered}$
$\begin{aligned} & \text { Service) } \\ & \end{aligned}$


distrust in communications and management organisations. In the UK, a 2016 EA poll indicated that only $45 \%$ of people living in at-risk areas appreciate their risk and only $7 \%$ identify any risk to their own property (Environment, Food and Rural Affairs Select Committee 2016). Similarly, independent polling by the 'Know Your Flood Risk' campaign (Davies 2015) reported that $31 \%$ of at risk households surveyed had no flood plan and would not know what to do in the event of flooding.

\section{Risk communication approaches and the adoption of resilient behaviours}

Research has therefore identified that the existing UK model of flood risk communication is not functioning as intended, with communications failing to meet user needs or match their experiential knowledge (Environment Agency 2010; Meyer et al. 2012; Fisher 2015). It has also been argued that by centralising and professionalising the production of risk information, local communities lose their ability to properly understand their local risk situation (Lane 2012; Bubeck et al. 2012). The outcome is that both the practice of communicating risk information and how information receivers interpret information may not actually be aligned with the stated purpose of flood risk communications in the UK. In this section we explore the fundamental research that underpins risk communication and examine why this might be the case.

Callon (1999) and Demeritt and Norbert (2014) have both proposed models for how risk is communicated, considering the direction of communication, the roles of the communicator and the receiver, and the purpose of the communication (Table 2).

Flood risk communications have a joint purpose of both transmitting information and also altering behaviour (Hagemeier-Klose and Wagner 2009) and can therefore be seen as a hybrid of the risk message model (RMM) or the public education model (PEM), and the risk information model (RIM). Research driving RIM-focused communications has explored a wide range of potential factors which influence the translation of risk information into behaviours: examples include previous experiences of a threat (Fielding et al. 2007; Hopkins and Warburton 2015); cultural, geographical, and socio-economic factors (Burningham et al. 2008; Bubeck et al. 2012); reliance on public flood protection (Terpstra and Gutteling 2008); trust/distrust in communications from a management authority (Terpstra 2011; Wachinger et al. 2013); or a need to protect an individual's sense of personal security against high levels of future uncertainty (Harries 2008; Willis et al. 2011).

An alternative approach to examining individual variables is proposed by Rogers (1975), who presents the protection motivation theory (PMT) model (Fig. 1). PMT explains and provides an overarching framework for the interplay between the disparate variables which may contribute to triggering behavioural responses from risk information. Rogers argues that individuals make their decision by appraising the severity and likelihood of their exposure (the threat appraisal) against the potential efficacy of potential protective behaviours (the coping appraisal), with their protection motivation representing the intervening stimulus which determines their actions.

Grothmann and Reusswigg (2006) and Bubeck et al. (2012) build upon Roger's work by expanding the sub-components of the threat and coping appraisals (Fig. 1), as well as identifying the potential for non-protective responses such as denial or wishful thinking, in situations where threat and/or coping appraisals are negative. This concept is supported 
Table 2 A comparison of the defining characteristics of risk communications models proposed by Callon (1999) and Demerit and Norbert (2014)

\begin{tabular}{llll}
\hline Model Direction & $\begin{array}{l}\text { Role of } \\
\text { communicators }\end{array}$ & $\begin{array}{l}\text { Role of } \\
\text { receivers }\end{array}$ & Purpose of communication \\
\hline
\end{tabular}

\section{Demerit and Norbert}

\begin{tabular}{|c|c|c|c|c|}
\hline Risk message & One & Educator & Passive & To inform ${ }^{a}$ \\
\hline Risk instrument & One & Educator & Passive & Behavioural alteration \\
\hline Risk dialogue & Two & Active participant & $\begin{array}{l}\text { Active } \\
\text { participant }^{\mathrm{b}}\end{array}$ & $\begin{array}{l}\text { To inform } \\
\text { Behavioural alteration }\end{array}$ \\
\hline Risk governance & Integrated $^{\mathrm{c}}$ & Active participant & $\begin{array}{l}\text { Active } \\
\text { participant }\end{array}$ & $\begin{array}{l}\text { Encourage participation } \\
\text { Create new knowledge/ } \\
\text { viewpoints }\end{array}$ \\
\hline \multicolumn{5}{|l|}{ Callon } \\
\hline Public education & One & Educator & Passive & To inform ${ }^{a}$ \\
\hline Public debate & Two & $\begin{array}{l}\text { Active } \\
\text { participant }^{\mathrm{d}}\end{array}$ & $\begin{array}{l}\text { Active } \\
\text { participant }^{\mathrm{e}}\end{array}$ & To inform ${ }^{a}$ \\
\hline $\begin{array}{l}\text { Co-production of } \\
\text { knowledge }\end{array}$ & Integrated $^{\mathrm{b}}$ & Active participant & $\begin{array}{l}\text { Active } \\
\text { participant }\end{array}$ & $\begin{array}{l}\text { Create shared knowledge/ } \\
\text { viewpoints }{ }^{\mathrm{f}}\end{array}$ \\
\hline
\end{tabular}

${ }^{a}$ Assumes rational action from receivers

${ }^{\mathrm{b}}$ Who should participate, why and how is seen as contested and dependent upon the purpose of the communication

${ }^{\mathrm{c}}$ Blurring of roles between knowledge producers and receivers

${ }^{\mathrm{d}}$ Privileged knowledge producers

${ }^{\mathrm{e}}$ Local knowledge intended to enrich scientific knowledge

${ }^{\mathrm{f}}$ Development of knowledge and viewpoints which are developed through the participatory process and are therefore shared by all participants

by research on 'learned helplessness' (Paton and Johnston 2001), where individuals see disaster events as uncontrollable and therefore assume that their impacts are in turn uncontrollable, triggering feelings of despair or helplessness (Paton and Johnston 2006).

PMT demonstrates the complex, contested, and highly personal nature of the linkage between communication and the adoption of protective behaviours. Comparison against the models of communication reveals the likely limitations of current communication approaches based on the RIM or PEM. These approaches, which assume a rational response from the receiver, are unlikely to address the complex nature of the threat and coping appraisals.

\section{Using participatory approaches to developing new ways to communicate flood risk}

We suggest that participatory working (Kindon et al. 2007) offers an opportunity to rethink how information can be communicated to those at risk by positioning people at the heart of flood risk communications. Participatory working re-imagines the traditional roles of experts and lay people (Bucchi and Neresini 2008; Landström et al. 2011; Lane et al. 2011) and considers circulation of different forms of expertise (Whitman et al. 2015), with participants working together as equals to co-produce shared knowledge and outputs (Mees 


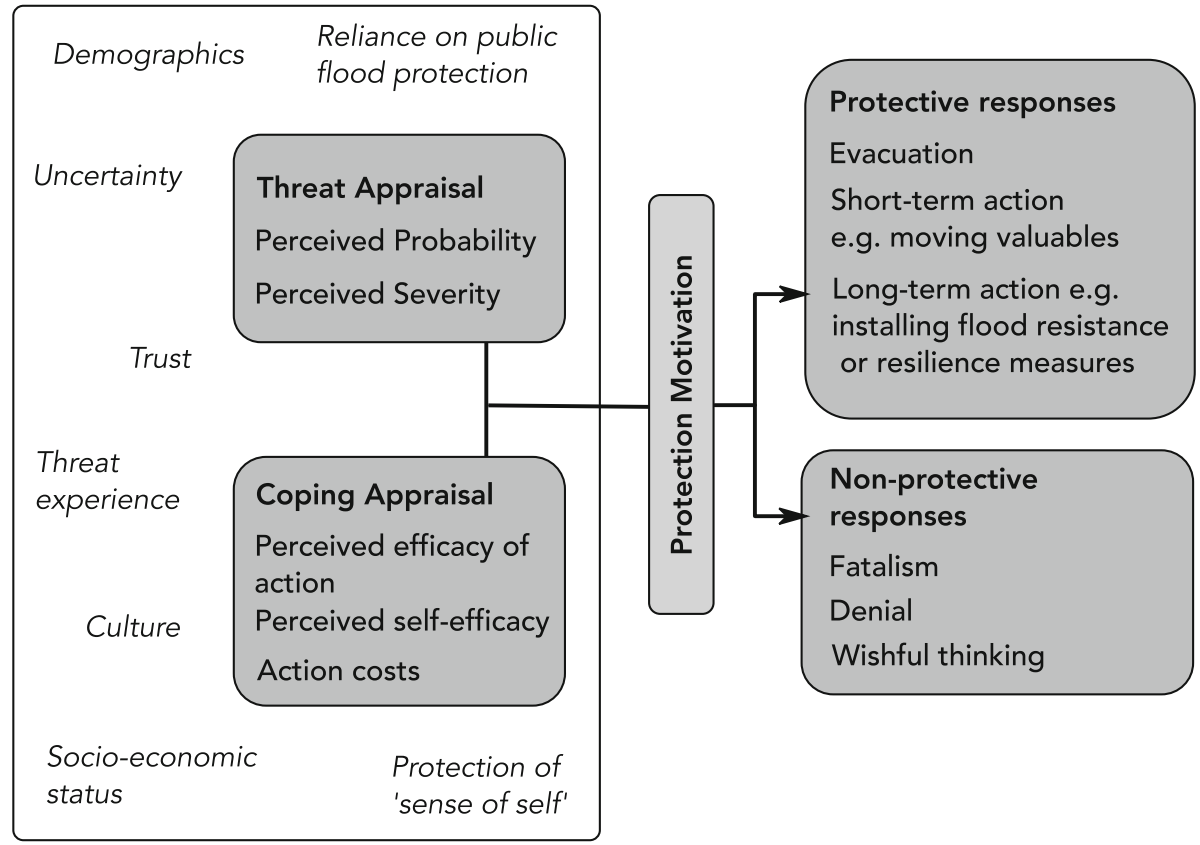

Fig. 1 The protection motivation theory model. Factors influencing a decision to take protective or nonprotective action in response to a threat. Shaded areas denote the PMT as proposed by Rogers (1975) and developed by Bubeck et al. (figure adapted from Bubeck et al. 2012), whilst unshaded areas denote individual factors which have been shown to impact on threat and coping appraisals and therefore an individual's protection motivation

et al. 2016). Participatory working approaches have been applied to a variety of environmental problems, including the co-production of options for managing local flood risk (Lane et al. 2011), the breaking down of borders between different organisations, professionals, and lay people involved in catchment-scale land management to manage floods (Bracken et al. 2016), and developing end-user specific research outputs regarding agricultural pollution (Whitman et al. 2015). To date, however, participatory practices have not been applied to flood risk communications, with recent research concluding only that participation was a useful approach for raising awareness or communicating flood risk complexity (Environment Agency 2012), or as a way of providing limited feedback on current communication approaches (Fisher 2015). These limited approaches to participation fail to exploit the potential of participatory working to open up the debate on what risk information is important and why. Here therefore we look to expand the participatory approaches demonstrated by previous studies into exploring the efficacy of current flood communications and, working together with a flood group of flood-affected locals, to coproduce alternative communications better suited to driving resilient behaviours.

\subsection{The Corbridge study area}

Corbridge (Fig. 2) has a long history of flooding; approximately 70 properties in Station Road and The Stanners are situated on the floodplain and are vulnerable to flooding. River level records date back to the 1700s (Archer et al. 2007a), and the area has a long history of 


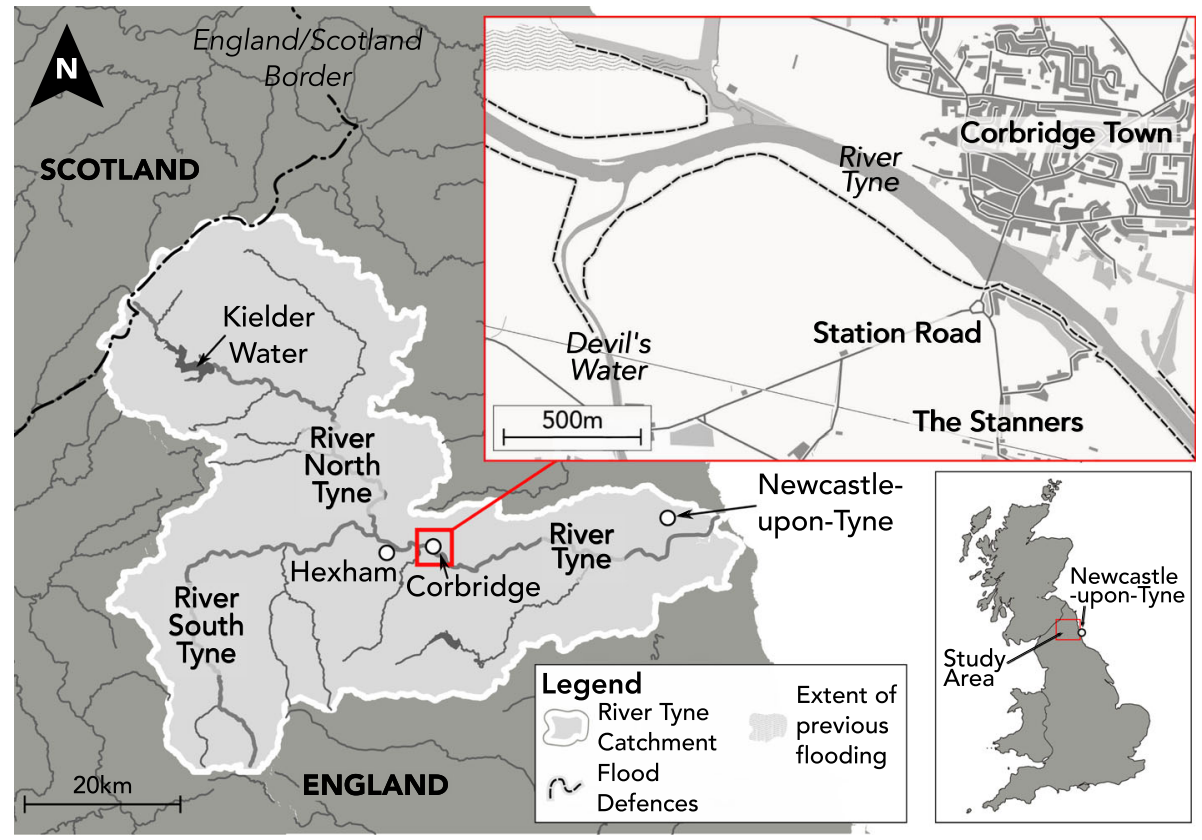

Fig. 2 The River Tyne catchment and Corbridge study area. The inset highlights the extent of the area considered during the research

flooding, including flooding in 2005 resulting from the collapse of a flood defence embankment (Archer et al. 2007b). This earlier damage led to flood defence improvements being carried out by the EA prior to a major flood on 5 December 2015, an event with an estimated return period of between 100 and 200 years (Marsh et al. 2016), which exceeded the design standard for the defences leading to serious flooding. All 70 at-risk properties were reported to have been flooded (Environment Agency 2016), some to depths of $>1.5 \mathrm{~m}$.

\subsection{The research approach}

In the summer of 2016, we undertook research to explore local knowledge about flooding in the Tyne Valley based on working together with local people to develop new approaches to communicating risk. Our aim was to blend academic research expertise with the experiences of Corbridge residents to re-imagine what flood risk information could be communicated and how it might be best presented. Figure 3 shows the multi-methods participatory approach developed.

\subsubsection{Understanding local knowledge and flood experience: workshops with the Corbridge Flood Action Group}

In Phase 1 we conducted several group mapping and discussion workshops with members of the local Corbridge Flood Action Group (CFAG). The purpose of these meetings was to assess local knowledge and experiences of flood risk. Using a grounded theory approach, following Charmaz (2011), the material produced by these workshops, the maps, the researchers' notes and the group discussions were integrated to identify key themes arising 


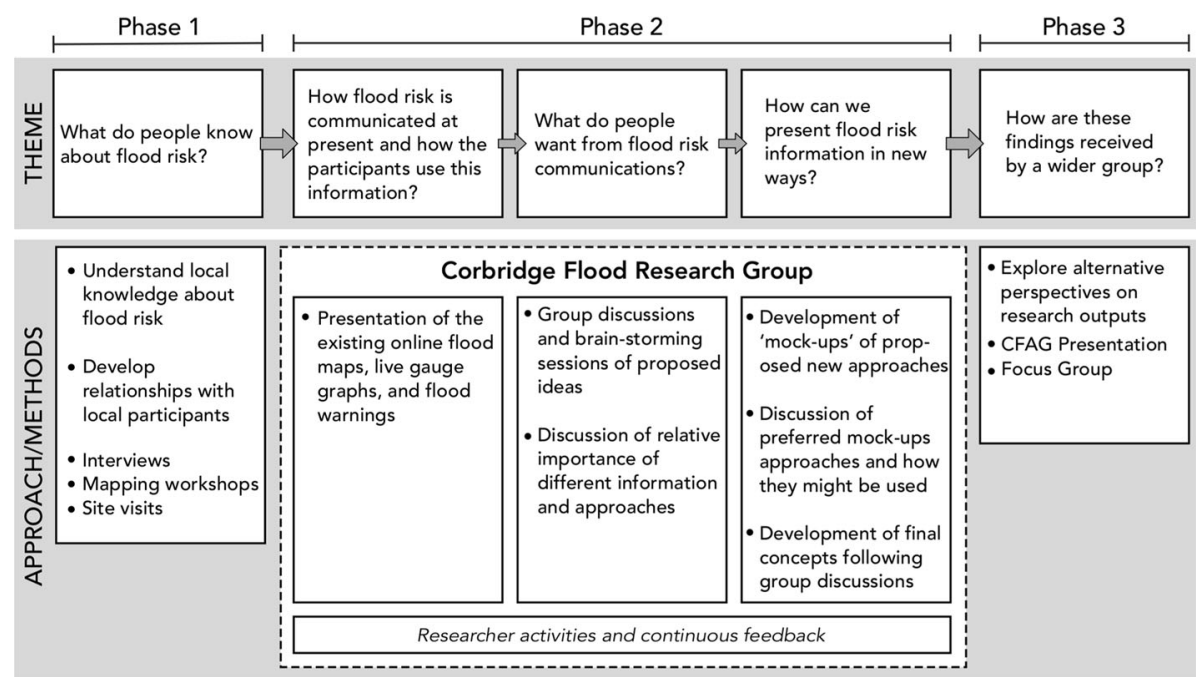

Fig. 3 The multi-methods research process

from the local experience of flooding. Using this approach we developed an understanding of the level of knowledge about, and engagement with, the flood risk problem, as well as developing a trusting relationship between the researchers and the CFAG.

\subsubsection{Adopting a participatory approach to developing new flood risk communications: the Corbridge Flood Research Group}

The relationship developed between the researchers and the CFAG during Phase 1 was instrumental in developing the Corbridge Flood Research Group (CFRG), which was developed through Phase 2 of the research. The CFRG was a group loosely modelled on the Environmental Competency Group used by Lane et al. (2011). Similar to Lane et al. the CFRG was set apart from traditional focus or consultation groups by its focus on the practice of knowledge creation as a collaborative process and the integration of local 'non-experts' into a practice of flood management usually carried out far removed from the local scale.

The CFRG consisted of six, self-selected members of the wider CFAG who had personal experiences of (five members), or interest in (one member), flooding at Corbridge. One of the researchers (Rollason) also took an active role in the group as a member, as opposed to a more traditional role as facilitator or group leader. Local members of the group contributed their experiential knowledge of flooding and flood communication, whilst Rollason (as an academic specialist and former professional flood manager in industry) brought expert technical knowledge and experience. By blending these two perspectives, the group was able to consider both the CFRG's communication desires and the practicalities of what could be achieved.

CFRG meetings were framed specifically to explore flood risk communications. The group met three times; only the theme of the first, 'how flood risk is currently communicated?' was predetermined. Subsequent meetings were driven by the group discussions and were predominantly unstructured, with participants determining what should be discussed and how. Meetings were audio-recorded, and field notes taken. After each meeting key discussion points were summarised, notes circulated to the group; all members thus 
participated in the iterative and ongoing development of the narrative being developed. Analysis of the material was undertaken throughout the process by adopting a flexible, mixed-method approach, situated within the principles of grounded theory (Knigge and Cope 2006; Charmaz 2011), for identifying and linking key areas of discussion. The discussions held with the group during CFRG1 and CFRG2 allowed Rollason to prepare a series of prototype interfaces for communication. The technical skills employed involved flood risk mapping using GIS software and running two-dimensional flood models to capture and present information. The prototypes were presented for group deliberation at CFRG3, with the group jointly choosing four concepts and then working together to produce a final, shared version which represented the agreed outputs from the group.

\subsubsection{Testing the prototypes outside the CFRG}

In the final stage of the research the prototypes were presented to a larger focus group consisting of eight members of CFAG (new to the research), Rollason and one original member of the CFRG. The design and purpose of the concepts were outlined, and the focus group discussed what they thought of the ideas, how they might be used, and any alternative ideas. The key aspects of this discussion were recorded during the focus group. No further amendment of the concepts was deemed necessary following discussions.

\section{Current flood risk communications: Do current approaches meet users' needs?}

\subsection{Understanding local knowledge and experiences of flooding}

The initial CFAG workshops and CFRG1 revealed that local participants had a wealth of experiential knowledge about flooding. Many also had an understanding of wider catchment processes developed through hobbies, such as fishing, or work. Despite this, few participants had expected the flooding to occur despite the receipt of an official flood warning (see Sect. 5.2), with many assuming that the recently completed flood defences would protect them, as one participant stated:

To be honest I didn't really believe it, because we had such faith in the flood defences that I actually didn't think we'd flood (Participant GW44)

Based on this commonly held belief, several participants made the decision not to evacuate, even when contacted by the emergency services (Oliver 2016). That participants were surprised by the flooding, and unsure of how to react to it, demonstrates that flood communications had not developed the resilience of the Corbridge community to respond to flooding after the 2005 flood. These findings highlighted the need to examine in more detail how current flood risk communications were used by participants and how they might be redesigned to better develop resilience.

\subsection{Reflections on current methods of flood risk communication}

The CFRG members were familiar with the principle communications provided by the EA and several had used them before the 2015 flood. Table 3 summarises the group's attitudes towards the current flood communications, and these are expanded upon below. 
Table 3 Summary of the CFRG perspectives on existing flood risk communications

\begin{tabular}{|c|c|c|}
\hline $\begin{array}{l}\text { Communication } \\
\text { type }\end{array}$ & $\begin{array}{l}\text { What the group thought about current } \\
\text { approaches }\end{array}$ & $\begin{array}{l}\text { What the group wanted from a future } \\
\text { approach }\end{array}$ \\
\hline $\begin{array}{l}\text { Active } \\
\text { communications } \\
\text { - Live gauges } \\
\text { - Flood warnings }\end{array}$ & $\begin{array}{l}\text { - Useful but lacking in explanatory } \\
\text { context and therefore difficult to } \\
\text { interpret } \\
\text { - A lack of future prediction makes it } \\
\text { difficult for people to know when and } \\
\text { how to respond to a potential flood }\end{array}$ & $\begin{array}{l}\text { - Forecast water levels } \\
\text { - Forecast of how serious a flood is likely } \\
\text { to be } \\
\text { - Water level information viewable at a } \\
\text { catchment scale }\end{array}$ \\
\hline $\begin{array}{l}\text { Passive } \\
\text { communications } \\
\text { - All non-live } \\
\text { flood maps }\end{array}$ & $\begin{array}{l}\text { - Too simplistic to be of any use except } \\
\text { when buying a house } \\
\text { - Complex probabilistic language is } \\
\text { difficult to interpret or place in context }\end{array}$ & $\begin{array}{l}\text { - Detailed impacts on individual } \\
\text { properties } \\
\text { - Integration of active and passive } \\
\text { communications } \\
\text { - Communication of flood dynamics and } \\
\text { timings rather than just extents to } \\
\text { provide explanatory context }\end{array}$ \\
\hline
\end{tabular}

Members classified the approaches into 'passive' (the static, online flood maps) and 'active' communications (the live river level gauges and flood warnings) during the group discussion held during CFRG1

The CFRG felt that current approaches did not provide them with enough information to understand their flood risk or make an informed decision of what to do when they received a flood warning. In the case of the passive communications, the simple presentation of a flood risk extent, lacking any information on how floods occur, provided them with no information that they could actually use to understand what the stated flood risk meant. Participants stated they only used these maps for buying their homes or negotiating insurance; other than this participants thought that the maps told them nothing that they did not know already:

For me, I know I'm in a high risk area so all it [the flood map] would tell me is what I know already (Participant GW44)

Some participants also expressed a lack of trust in how the maps had been produced, as one participant explained:

Originally, when they did the first online extreme flood map they drew the lines through the centre of the church [...], and I said "if it's getting to that level, it's coming down my chimney" (Participant AK97)

The church at Corbridge sits approximately $16 \mathrm{~m}$ above the floodplain. The group member still linked this experience and his distrust of those original maps to the current flood maps which appear superficially the same. The advancements in modelling and data since the production of the early maps are not evident in the way the maps are communicated, and information on how they are actually produced is not publicly available.

Participants were much more engaged with the active communications, particularly the online availability of real-time river levels. Several CFRG members noted that they watched gauges upstream of Corbridge to try and judge how river levels might change at Corbridge in the near future. However, all participants expressed frustration with the lack of forecast river levels, which did not allow them to judge when flooding might occur, or how severe flooding of their homes might be in comparison with past events. This was a particular problem when participants received flood alerts, preliminary warnings that flooding might occur in the near future. These alerts, issued some time before formal flood warnings, are intended to prompt people to begin monitoring local river levels and prepare 
to take protective action. However, participants felt that the lack of forecast information left them unable to judge what to do and when.

Fundamentally, participants felt that the information they were being provided currently told them when to act, but did not provide them with enough information to judge what it was feasible for them to do, or to what extent they should take action. As one participant noted regarding the 2015 floods:

When we put things up high, not thinking that when the river comes over the water was going to be so high it would upend all those things, so everything I put up high to save we lost (Participant GW44)

\subsection{What information do users want in flood communications?}

CFRG2 focused on the information that people actually wanted from flood communications to allow them to understand their risk and take action, setting aside for the moment the practicalities of whether or not such information could be provided. The discussions reflected their initial criticisms of existing communications, focusing particularly on understanding the severity of the risk, and therefore what degree of action they could and should take (Table 3). Ultimately, group members wanted flood levels to be forecast, and a specific linkage between what these flood levels meant for their properties and what they could do in response, for example how high they needed to lift valuables:

What you need is the starkest information, [...] this level [in the river] means that level [on the floodplain], means this amount of water in your house (Participant MJ33)

I want to know [...] if it's that high, I'm going to do this, if it's going to be like 2005, I need to do that, because that was much less flooding (Participant GW44)

These discussions encompassed both passive and active communications, with participants generally agreeing that active communications, such as the river level graphs, should be more specifically linked to the passive communications, which could provide more indepth and detailed information on property-level impacts.

Some group members were concerned that providing more complex information would be confusing and potentially undermine responses to flooding. As a result, the group discussed how it was necessary to communicate flooding dynamics, for example how, when, and where flooding might occur, in order to be able to effectively interpret local flood risk. Participants referred to this type of information as contextual information, examples of which included where and when flood defences might be over-topped and how flood water might flow across the floodplain in order to flood their properties. This potentially reflects the relatively complex dynamics of the 2015 flood, where the principle areas of defence over-topping were out of sight of participants properties, and therefore flooding occurred from an unexpected direction.

\section{Working together on new approaches to communicating flood risk}

Between CFRG2 and CFRG3 a series of draft prototypes of alternative passive and active flood risk communications were developed. Six prototypes were originally produced, exploring different types of information that could be communicated and different ways of 
communicating it (Table 4). Although the CFRG2 discussions had considered participants' information aspirations without considering the practicalities of implementing them, the group felt that it was important, in producing the prototypes, to consider how these ideas might be implemented in practice. Thus, where possible, proposals draw inspiration from existing examples of flood risk communications in other countries, proposed methods drawn from the literature, or examples of communications drawn from other fields (Table 4).

The prototypes were the focus of CFRG3. From the suite of initial concepts developed, the group considered four to be particularly useful (Fig. 4). These four were considered by

Table 4 Summary of the initial prototypes for new passive and active flood communications produced between CFRG2 and CFRG3 to communicate flood risk in different ways

\begin{tabular}{|c|c|c|c|}
\hline \multicolumn{2}{|c|}{ Mock-up } & \multirow{2}{*}{$\begin{array}{l}\text { Focus of the approach } \\
\text { Shows the status of river gauges across } \\
\text { the Tyne catchment indicating } \\
\text { current status and rate of change of } \\
\text { status where applicable }\end{array}$} & \multirow{2}{*}{$\frac{\text { Sources of inspiration }}{\text { Fishpal website (Fishpal.com) }}$} \\
\hline $1 \mathrm{a}$ & $\begin{array}{l}\text { Catchment-wide } \\
\text { gauge map }\end{array}$ & & \\
\hline $1 b$ & $\begin{array}{l}\text { Catchment-wide } \\
\text { gauge map, } \\
\text { zoomed in } \\
\text { example }\end{array}$ & $\begin{array}{l}\text { Shows current flood warnings and } \\
\text { status of gauges in a zoomed in } \\
\text { fashion }\end{array}$ & $\begin{array}{l}\text { Existing flood communications maps } \\
\text { and researcher experience }\end{array}$ \\
\hline 2 & $\begin{array}{l}\text { Gauge graph } \\
\text { examples } \\
\text { dashboard }\end{array}$ & $\begin{array}{l}\text { Shows multiple gauges in a single } \\
\text { 'dashboard' } \\
\text { Gauges display different options: } \\
\text { 1. Current approach } \\
\text { 2. Current approach with historical } \\
\text { hydrograph overlay } \\
\text { 3. Current approach with future water } \\
\text { level prediction } \\
\text { 4. Current approach with both (2) and } \\
\text { (3) }\end{array}$ & $\begin{array}{l}\text { Proposed alternative approaches were } \\
\text { based on } \\
\text { 1. Current display options } \\
\text { 2. With research interpretation of } \\
\text { CFRG suggestions } \\
\text { 3. Proposed prediction options from } \\
\text { Leedal et al. (2012) }\end{array}$ \\
\hline $3 a$ & $\begin{array}{l}\text { Flood impacts } \\
\text { explorer-flood } \\
\text { depths }\end{array}$ & $\begin{array}{l}\text { Shows modelled flood depths from a } \\
\text { previous flood event (2016) }\end{array}$ & $\begin{array}{l}\text { Existing flood depth maps and } \\
\text { researcher experience }\end{array}$ \\
\hline $3 b$ & $\begin{array}{l}\text { Flood impacts } \\
\text { explorer-flood } \\
\text { pathways }\end{array}$ & $\begin{array}{l}\text { Shows modelled flood depths and } \\
\text { explanatory context of key flood } \\
\text { pathways and timings. Shows linked } \\
\text { flood hydrograph indicating water } \\
\text { levels at which key mechanisms } \\
\text { become active }\end{array}$ & $\begin{array}{l}\text { Flood depth maps and from researcher } \\
\text { interpretation of key information } \\
\text { requested by the CFRG members }\end{array}$ \\
\hline $3 c$ & $\begin{array}{l}\text { Flood impacts } \\
\text { explorer- } \\
\text { historical } \\
\text { frequency }\end{array}$ & $\begin{array}{l}\text { Shows modelled flood depths with } \\
\text { indication of historical frequency of } \\
\text { flooding events of given magnitude }\end{array}$ & $\begin{array}{l}\text { USGS flood inundation mapper } \\
\text { 'historical flooding' information } \\
\text { (United States Geological Survey } \\
\text { 2016) }\end{array}$ \\
\hline $3 d$ & $\begin{array}{l}\text { Flood levels } \\
\text { explorer- } \\
\text { potential water } \\
\text { levels }\end{array}$ & $\begin{array}{l}\text { Shows user variable water level } \\
\text { indicator, demonstrating potential } \\
\text { flood extent and depth at different } \\
\text { gauged water levels. Could be based } \\
\text { on either local assessment of a digital } \\
\text { elevation model, or a model outputs } \\
\text { library (for example, see Hogan Carr } \\
\text { et al. 2016) }\end{array}$ & $\begin{array}{l}\text { USGS flood inundation mapper ‘Flood } \\
\text { Inundation Map Library’ (United } \\
\text { States Geological Survey 2016; } \\
\text { Hogan Carr et al. 2016) }\end{array}$ \\
\hline
\end{tabular}




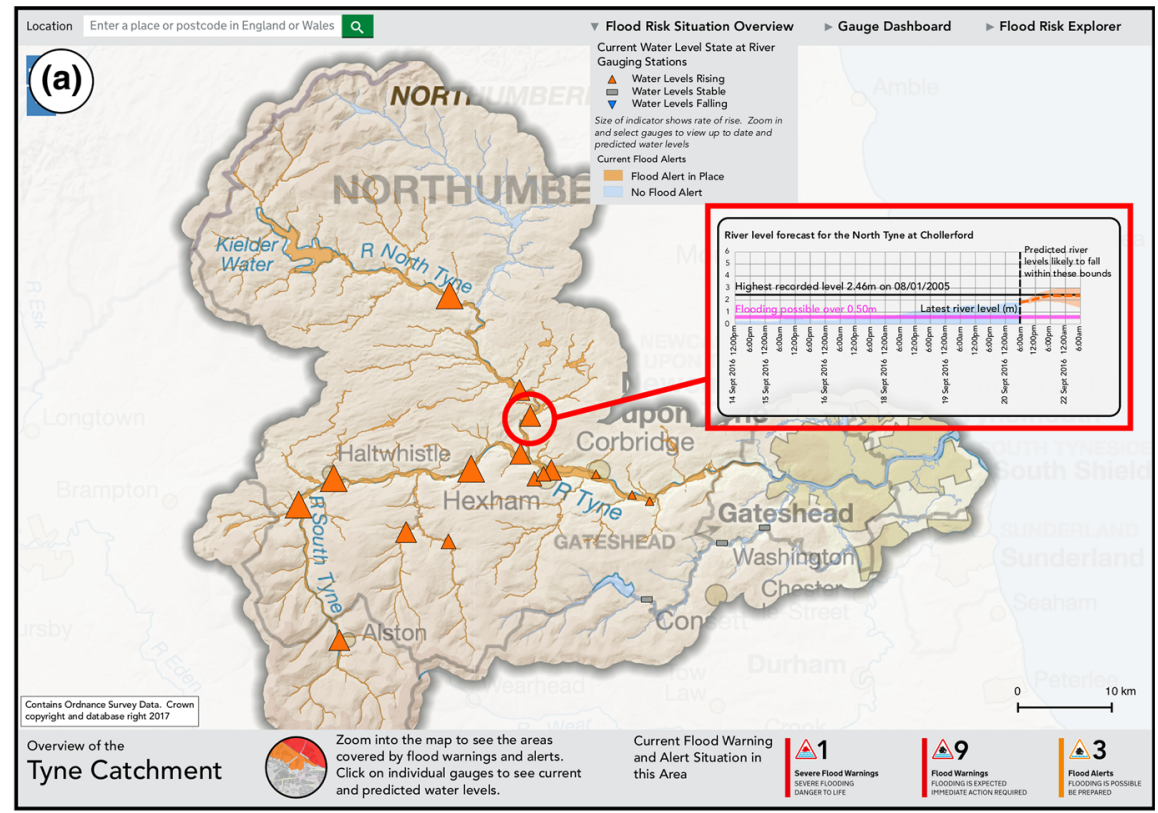

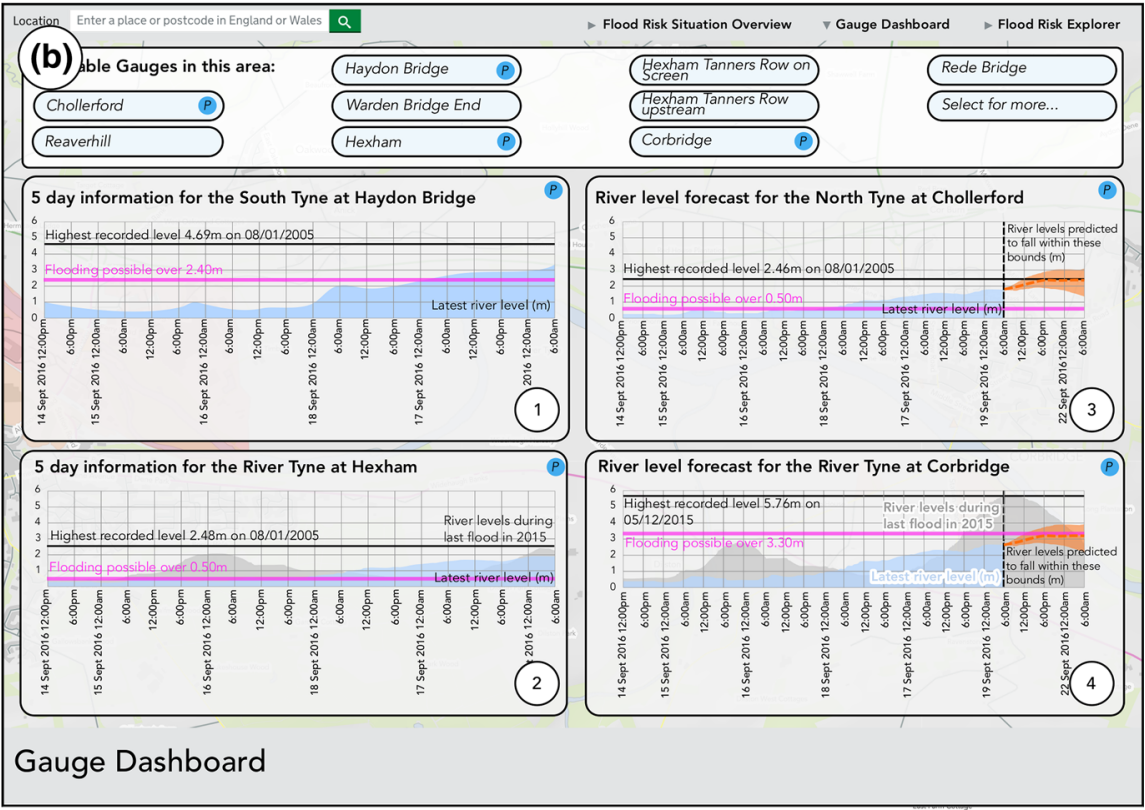

Fig. 4 Flood risk communication concepts adopted by the CFRG (concept numbers relate to details in Table 4). a CFRG Concept 1a showing the catchment-wide overview of the river gauging station status. b CFRG Concept 2 showing a proposed gauge dashboard allowing users to 'pin' multiple gauges of their choice into a single place for rapid review of how river levels upstream are responding to rainfall. c CFRG Concept $3 \mathrm{~b}$ outlining a detailed assessment of historical flood dynamics (in this case the December 2016 flood event). d CFRG Concept $3 \mathrm{~d}$ shows a user-selected water level from the Corbridge gauge and displays the corresponding extent and depth of flooding based on simple water level interpolation 

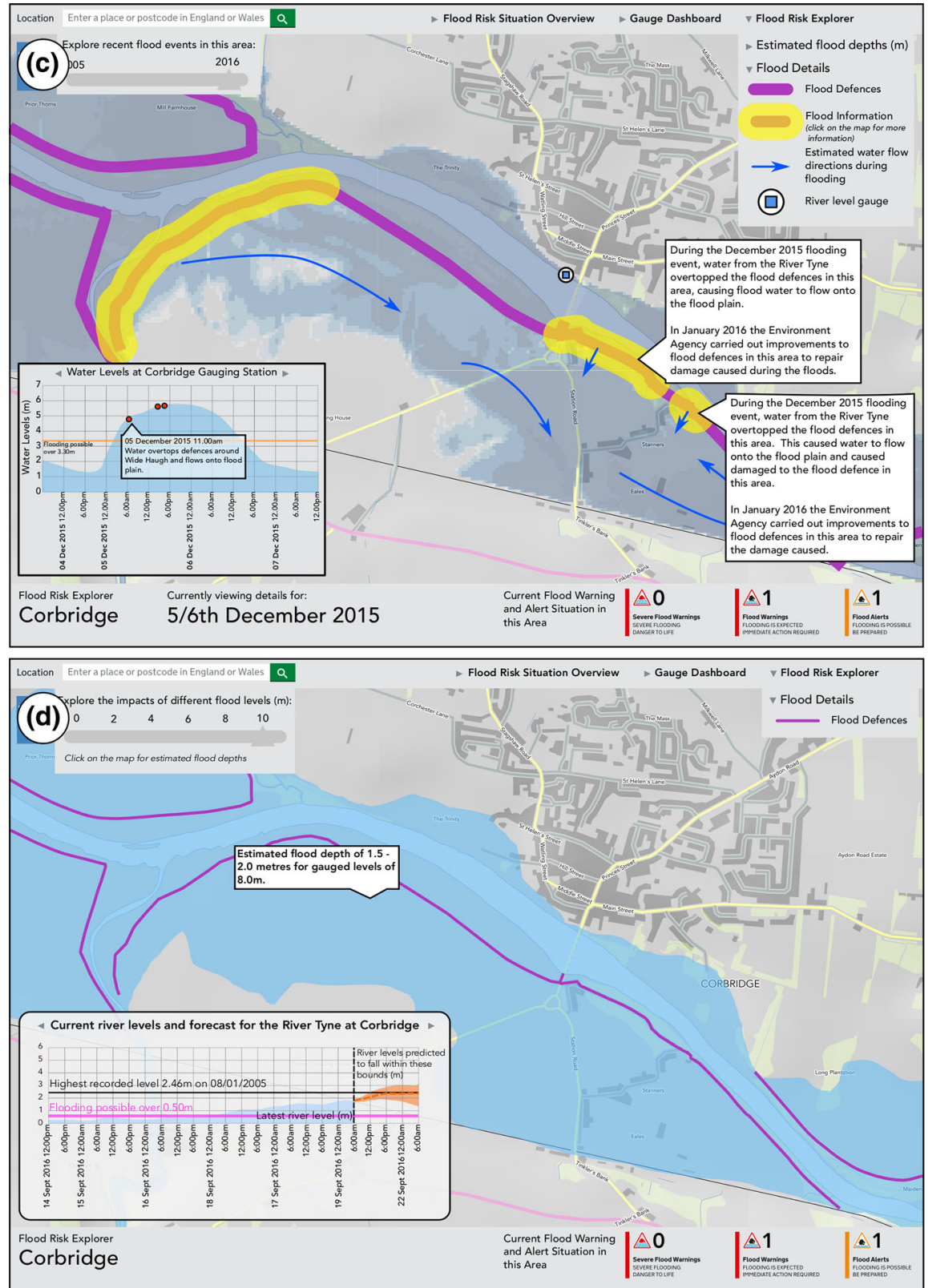

Fig. 4 continued

the local participants to give them the information they felt they needed to understand the risk of flooding, but also to make informed decisions about what action to take, and when, for future floods. These four prototypes were further developed by the group 
during and after CFRG3, and those shown in Fig. 4 represent the final, agreed outputs from the group.

The four prototypes adopted by the group reflect the CFRG's two core desires:

1. to be able to take responsibility for effectively monitoring their flood risk and judge, through forecast information, how significant any flooding might be (Fig. 4a, b).

2. to have a detailed understanding of how flooding might occur based on a knowledge of past flooding dynamics (Fig. 4c) and to be able to link forecast flooding information with the potential impacts on their own properties, allowing them to judge what action they could take in response.

Figure $4 \mathrm{a}$ shows the catchment-wide overview of the river gauging station status, enabling users to quickly assess how the catchment is responding to rainfall. This prototype map is linked specifically to individual gauge records allowing users to select and explore specific sites in more detail. Inspired by the online angling tool 'Fishpal' (Fishpal.com) used by one of the CFRG participants, the group members felt this tool allowed them to easily monitor catchment-scale river response, using their knowledge of how rainfall in different areas of the catchment translated into flood risk at Corbridge.

Figure $4 \mathrm{~b}$ outlines a prototype gauge dashboard which allows users to 'pin' multiple gauges of their choice into a single place for rapid review of how river levels upstream are responding to rainfall. This prototype answers group members annoyance with only being able to view one gauge at a time using the current system. This prototype also reflects different options for how gauged levels should be displayed, which were also discussed by the CFRG: (1) current approach adopted by the Environment Agency; (2) current approach with an overlay comparing current levels with a historical hydrograph; (3) current approach including predicted future water levels based on the method proposed by Leedal et al. (2012); or (4) current approach with both (2) and (3). CFRG participants felt that forecast water levels (as in 3) allowed them to plan protective actions in advance of flooding occurring by anticipating when they would need to take certain actions, whilst historical comparisons (such as that shown in 2) allowed them to contextualise the significance of predictions and therefore judge what level of protective action was necessary.

Figure $4 \mathrm{c}$ presents a detailed assessment of historical flood dynamics (in this case the December 2015 flood event). In this prototype users would be able to select different elements to be provided with a detailed account of how flooding occurred, and what action might have been taken in response. The hydrograph allows users to identify water levels at which different flooding mechanisms begin to operate. CFRG members felt this map developed their understanding of how flooding occurred and when, allowing them to understand the significance of local gauged river levels.

Figure $4 \mathrm{~d}$ shows the simulated extent and depth of potential flooding based on a userselected water level for the Corbridge gauge. This prototype was inspired by the United States Geological Survey 'Flood Inundation Map Library' (United States Geological Survey 2016). Current and predicted water levels at Corbridge are displayed on the gauge display to allow users to link current and predicted water levels with their evaluation of potential impacts. CFRG participants felt this simple linkage between river levels and potential floodplain impacts was important for correctly interpreting what forecast river levels might mean and for demonstrating what degree of protective action was needed in different situations. 


\section{Scaling up: testing the prototypes with the wider Corbridge Flood Action Group}

The four updated prototypes were presented to the wider CFAG at a group meeting and also at a smaller focus group. The prototypes were well received by the focus group (Table 5), with the underlying themes of understanding flood dynamics, flood impacts and future prediction being reflected in the discussions. All participants saw the potential for the active communications to enable them to take action to reduce the impact of future floods.

The prototype in Fig. 4c provoked a different response to that of the CFRG. The focus group members thought that this map was not for them to use in preparing for flooding, but instead was as a tool for them to use to engage more effectively with the EA about ongoing FRM on a more even information footing:

I think that information is important for us to see, so that we can have intelligent conversations with the Environment Agency (focus group participant)

Instead, to prepare for a flood in the near future, the focus group participants preferred the simple water level model shown in Fig. 4d.

This discussion highlights the complex interactions between individual users and the different approaches to communicating flood risk and the difficulties of presenting only a small variety of information in order to represent a complex and dynamic threat such as flooding.

Table 5 Responses to the CFRG mock-ups from the Corbridge Flood Action Group Focus Group (CFRG mock-up numbers refer to Table 5)

\begin{tabular}{|c|c|}
\hline CFRG mock-up & Summary of Flood Group Focus Group responses \\
\hline 1a Gauges overview & $\begin{array}{l}\text { - Very useful for understanding the overall view of the catchment } \\
\text { - Can look at the whole river all at once and can be used to understand } \\
\text { how large a flood might be } \\
\text { - Would need to be able to understand what the information meant for } \\
\text { flood impacts at Corbridge } \\
\text { - Would like to see predictors of water level increases on the overview } \\
\text { map }\end{array}$ \\
\hline 2 Gauge dashboard & $\begin{array}{l}\text { - Predicted and historical information both useful in indicating potential } \\
\text { magnitude and also providing context for understanding what levels } \\
\text { mean } \\
\text { - Do not consider (4) to be too complex } \\
\text { - Would like an indication of key trigger points, for example level at } \\
\text { which defence over-topping begins } \\
\text { - Uncertainty very important in predictions of water levels to avoid users } \\
\text { minimising future warnings }\end{array}$ \\
\hline $\begin{array}{l}\text { 3b Flood explorer, pathways } \\
\text { and timings }\end{array}$ & $\begin{array}{l}\text { - Provides a vivid contextual understanding of what occurred during } \\
\text { previous floods } \\
\text { - Not necessary or interpreting current or future events, gauged, real- } \\
\text { time information much better for this } \\
\text { - Much more useful for engaging with the EA regarding flood } \\
\text { management activities }\end{array}$ \\
\hline $\begin{array}{l}\text { 3d Flood explorer, user- } \\
\text { simulated flood depths }\end{array}$ & $\begin{array}{l}\text { - Very useful for understanding flood impacts and allowing users to link } \\
\text { gauged information with potential flood depths } \\
\text { - More useful than the historical pathways and timings idea }\end{array}$ \\
\hline
\end{tabular}




\section{Discussion}

In this section we bring together the experience of the CFRG experiment with theories of risk communication. We argue that participation such as that demonstrated by the CFRG must play a role in developing future flood communications, especially in light of the shift from flood defence to flood management and the resulting distribution of FRM responsibilities onto those at risk (Butler and Pidgeon 2011). Such involvement will enable responsible agencies to better communicate flood risk in new ways, empowering those at risk to apply their local knowledge and experience to improve their resilience in the face of flood events.

\subsection{Implications for current flood risk communications}

The research undertaken has shown that there are severe limitations to current flood risk communication approaches which prioritise simple threat messages. The PMT model (Rogers 1975) can be used to analyse the responses of the CFRG to the existing flood communications and their desire for alternative approaches, focusing particularly on the ideas of the threat and coping appraisal (Grothmann and Reusswig 2006). The CFRG saw no useful information in the existing passive maps, which suggests that this approach does not support the development of threat appraisal. The lack of information on flood dynamics also provides no basis on which users can judge for themselves how communicated risk information might translate into an impact on their own property. In this context, threat appraisal is reliant on previous experiences, whether personal or vicarious. In the Corbridge context this wholly underestimated the threat, resulting in a non-protective response based on 'wishful thinking' regarding the recently completed flood defence works. Hopkins and Warburton (2015) refer to this paradox as the 'prison of experience', in which infrequent or unrepresentative events imprint themselves into subjective knowledge as representative experiences to be drawn on in the future. CFRG participants' desire for detailed information on past local flooding characteristics or the simple flood depth simulator can be seen as an attempt to place their experiences in a wider context, breaking out of the prison of experience and establishing a more holistic understanding.

Both the passive and active communications assessments also suggest a failure of current approaches to establish a meaningful coping appraisal, particularly in relation to the judgement of how much time participants in this study had to react and what degree of action they should, or could, take. Several participants expressed surprise at the prototype flood map showing flood dynamics, which highlighted over-topping of upstream defences approximately $4 \mathrm{~h}$ prior to property flooding occurring. These participants had no understanding from the current flood maps (which do not show information such as areas of potential over-topping) that flooding might either be inevitable or occurring, or that they potentially had several hours in which to prepare or act. Neither were participants able to accurately judge the degree to which they should prepare based on the live gauged information, since this online information does not currently offer information on predicted water levels. This led to negative coping appraisals and the adoption of non-protective behaviours, where participants either ignored what might be happening or took ineffective action. In this context, the Group's desire to see whole-catchment-scale information, which incorporates future predictions, can be seen as building not just their personal appraisal of the threat, but also their coping appraisal. Understanding the threat allows them to feel in control of their own flood risk situation and to make their own decisions, rather than 
reacting blindly to flood warnings; a situation that participants said left them very stressed and uncertain.

\subsection{Future flood risk communications: participation as a vehicle for developing resilience through flood literacy}

Viewed in the context of the PMT, current flood risk communications could therefore be judged to be counterproductive; they attempt to provoke a heightened perception of flood risk, without providing the information required by users to establish strong, positive threat and coping appraisals. Without developing coping appraisals, users adopt the kinds of nonprotective behaviours proposed by Bubeck et al. (2012), ignoring, rejecting or misinterpreting official risk information to make them feel more secure in the face of extreme uncertainty (Harries 2008). These behaviours reduce community resilience by increasing the shock of events when they occur unexpectedly or do not match individuals previous experiences; increase individual hazard through refusals to evacuate; or foster learned helplessness when believed protective behaviours fail or have no effect.

To encourage positive threat and coping appraisals future flood communications need to move away from the simplistic flood threat messages that are currently cascaded to people at risk. Instead, and as the four prototypes created here demonstrate, communications should provide more detailed, holistic hazard information. This type of information, rather than relying on raising risk perception alone, seeks to develop a local 'flood literacy' by fostering local knowledge about flooding. Flood literacy repositions those at risk as active agents in managing local flood risk, able to make their own judgements and decisions on risk and protective behaviour, rather relying on expert knowledge (Willis et al. 2011). By empowering people in this way, flood literacy develops local resilience in a way in which simple, threat-based communications cannot: it provides at-risk individuals and communities with the information necessary to (1) assess their personal level of risk and how they might be affected, (2) determine when a flood might be about to occur and how it might affect them, and (3) determine appropriate actions by which they might mitigate potential flood impacts.

To encourage effective flood literacy through improved flood risk communications, there is a need to re-establish resilience as a process grounded in relationships, social learning and dialogue (Twigger-Ross et al. 2011, 2014; Benson et al. 2016), rather than 'hard' infrastructure or property (McBain et al. 2010). Participatory approaches offer a potential avenue through which the reinvigoration of resilience in this fashion might occur. The results of our research demonstrate the importance of working together with end-users in developing new solutions to flood risk problems, similar to the findings of previous participatory research (Landström et al. 2011; Lane et al. 2011; Whitman et al. 2015; Bracken et al. 2016). The practices of participatory working help to unify local and official perspectives on flood risk and develop local capacity to understand and take action (Pain 2004) in ways that established approaches to communication have been shown not to be able to achieve. 


\section{Conclusions}

The last three decades have seen rapid changes in our approaches to addressing flood risk, and a professional acceptance that flooding cannot be prevented and must instead be managed. Societal resilience to floods has emerged as a key pillar of this new approach to 'living with floods'. Changes in policy have increasingly focused on the resilience of critical infrastructure, and developing community resilience has increasingly been undertaken through an educational model of risk communication. However, research suggests that this approach is failing to develop individual and community capacities for understanding and responding to floods in a resilient manner.

The research presented here has demonstrated the application of participatory approaches to exploring the linkage between flood risk communication, individual behaviour and generating resilience. We have worked together with a competency group drawn from a flood-affected community to understand how they use and interpret current flood risk communications, what information is important to them in understanding and responding to floods in a resilient manner and how could information be better communicated. Our conclusions are as follows:

1. Current approaches to flood risk communications fail to meet user needs in understanding flood risk or allowing personal judgements of how and when to act. Through a reliance on communicating simple, threat-based messages rather than developing in-depth understanding, current communications heighten threat appraisal, but diminish coping appraisal. This promotes non-protective behaviours, either through wishful thinking and over-reliance on management organisations, or through denial and learned helplessness.

2. Users desire a greater range of information about floods, including locally specific information on flood dynamics, which would allow them to understand their personal flood risk situation and how floods will affect them. Delivering this information is vital to enable those at risk to judge what protective actions they can take, and when they should take action. Our results demonstrate that users desire forecast information beyond what is provided currently. Without forecasts of river levels or flood extents, users are unable to judge the potential severity of future flooding, which means they are reluctant or unwilling to take action blindly.

3. There are a great variety of different perspectives on how flood risk should be communicated and the purpose of these communications, even within a small area. The complexity of the risk message-behaviour interface means that one message cannot be tailored to all perspectives. We propose a communications model which is instead focused on the development of 'flood literacy', where communities and individuals are empowered to develop their own knowledge about local flood risk and how they can act to manage it.

4. Flood literacy can reinvigorate flood communications as a tool for developing flood resilience by establishing flood communications as a two-way dialogue focused on the development of shared, locally grounded knowledge. Participatory working approaches represent a vehicle through which communications and resilience can be linked. Resilience and participation are both grounded in the principles of trust, the development of relationships, and the co-production of knowledge and solutions. Participation therefore has the potential to offer a solution, re-imagine our approaches to communication, integrate alternative perspectives and place 'knowledge consumers' at the heart of the process. 
5. We propose four co-produced prototype user interfaces which can deliver the information needed to help those at risk develop flood literacy.

The challenge of quantifying how new and innovative modes of knowledge creation, communications and relationship-building can provide valuable opportunities for bettering flood risk management remains. However, the approaches described here have important implications for how we communicate flood risk and how we work alongside those living with risk to develop more flood-resilient communities.

Acknowledgements The authors would like to thank the members of the Corbridge Flood Action Group for their participation in this study, and particularly those who gave of their time to be involved in the Flood Research Group. We would also like to thank the two anonymous reviewers for their comments which helped shape the final manuscript.

Funding This work was supported by the Natural Environments Research Council [Grant Number NE/ L002590/1]. Data presented in this manuscript can be obtained by contacting ER.

Open Access This article is distributed under the terms of the Creative Commons Attribution 4.0 International License (http://creativecommons.org/licenses/by/4.0/), which permits unrestricted use, distribution, and reproduction in any medium, provided you give appropriate credit to the original author(s) and the source, provide a link to the Creative Commons license, and indicate if changes were made.

\section{References}

Archer DR, Leesch F, Harwood K (2007a) Assessment of severity of the extreme River Tyne flood in January 2005 using gauged and historical information. Hydrol Sci J 52:992-1003. https://doi.org/10. 1623/hysj.52.5.992

Archer DR, Leesch F, Harwood K (2007b) Learning from the extreme River Tyne flood in January 2005. Water Environ J 21:133-141. https://doi.org/10.1111/j.1747-6593.2006.00058.x

Benson D, Lorenzoni I, Cook H (2016) Evaluating social learning in England flood risk management: an ‘individual-community interaction’ perspective. Environ Sci Policy 55:326-334. https://doi.org/10. 1016/j.envsci.2015.05.013

Bracken LJ, Oughton EA, Donaldson A et al (2016) Flood risk management, an approach to managing cross-border hazards. Nat Hazards. https://doi.org/10.1007/s11069-016-2284-2

Bubeck P, Botzen WJW, Aerts JCJH (2012) A review of risk perceptions and other factors that influence flood mitigation behavior: review of flood risk perceptions. Risk Anal 32:1481-1495. https://doi.org/ 10.1111/j.1539-6924.2011.01783.x

Bucchi M, Neresini F (2008) Science and public participation. In: Hackett EJ, Amsterdamska O, Lynch M, Wajcman J (eds) The handbook of science and technology studies, 3rd edn. MIT Press, Cambridge, pp 449-472 (Published in cooperation with the Society for the Social Studies of Science)

Burningham K, Fielding J, Thrush D (2008) 'It'll never happen to me': understanding public awareness of local flood risk. Disasters 32:216-238. https://doi.org/10.1111/j.1467-7717.2007.01036.x

Burns WJ, Slovic P (2012) Risk perception and behaviors: anticipating and responding to crises: risk perception and behaviors. Risk Anal 32:579-582. https://doi.org/10.1111/j.1539-6924.2012.01791.x

Butler C, Pidgeon N (2011) From 'flood Defence' to 'flood risk management': exploring governance, responsibility, and blame. Environ Plan C Gov Policy 29:533-547. https://doi.org/10.1068/c09181j

Callon M (1999) The role of lay people in the production and dissemination of scientific knowledge. Sci Technol Soc 4:81-94. https://doi.org/10.1177/097172189900400106

Charmaz K (2011) A constructivist grounded theory analysis of losing and regaining a valued self. In: Wertz FJ (ed) Five ways of doing qualitative analysis: phenomenological psychology, grounded theory, discourse analysis, narrative research, and intuitive inquiry. Guilford Press, New York, pp 165-204

Chatterton J, Viavattene C, Morris J et al (2010) The costs of the summer 2007 floods in England. Environment Agency, Bristol

Davies R (2015) Two-thirds of UK Households fail to check flood risk levels. In: FloodList. http://floodlist. com/protection/two-thirds-uk-households-fail-to-check-flood-risk. Accessed 18 June 2015

de Moel H, van Alphen J, Aerts JCJH (2009) Flood maps in Europe-methods, availability and use. Nat Hazards Earth Syst Sci 9:289-301. https://doi.org/10.5194/nhess-9-289-2009 
Demeritt D, Norbert S (2014) Models of best practice in flood risk communication and management. Environ Hazards 13:313-328. https://doi.org/10.1080/17477891.2014.924897

Environment Agency (2009) Flooding in England: a national assessment of flood risk

Environment Agency (2010) Flood and coastal risk management risk mapping strategy 2010-2015

Environment Agency (2011) National flood and coastal erosion risk management strategy for England. https://www.gov.uk/government/publications/national-flood-and-coastal-erosion-risk-managementstrategy-for-england. Accessed 13 Oct 2014

Environment Agency (2012) Recommendations for flood mapping in England and Wales: findings from the RISK MAP ERA-NET CRUE. Environment Agency, Bristol

Environment Agency (2016) Impact report winter flooding 2015-16-Northumberland, Durham and Tees Area

Environment, Food and Rural Affairs Select Committee (2016) Future flood prevention. In: www. parliament.uk. http://www.publications.parliament.uk/pa/cm201617/cmselect/cmenvfru/115/11502. htm. Accessed 15 Nov 2016

European Parliament and the Council (2007) Directive 2007/60/EC of the European Parliament and of the Council of 23 October 2007 on the assessment and management of flood risks

EXCIMAP (2007a) Handbook on good practices for flood mapping in Europe

EXCIMAP (2007b) Atlas of flood maps

Fishpal.com FishPal.com. http://www.fishpal.com/. Accessed 12 Apr 2017

Fielding J, Burningham K, Thrush D, Catt R (2007) Public response to flood warning. Environment Agency, Bristol

Fischhoff B, Bostrom A, Quadrel MJ (1993) Risk perception and communication. Annu Rev Public Health 14:183-203. https://doi.org/10.1146/annurev.pu.14.050193.001151

Fisher H (2015) Public dialogues on flood risk communication. Environment Agency, Bristol

Flood Information Service Flood Information Service (2017) https://flood-warning-information.service.gov. uk/. Accessed 12 Apr 2017

Gilissen HK, Alexander M, Matczak P et al (2016) A framework for evaluating the effectiveness of flood emergency management systems in Europe. Ecol Soc. https://doi.org/10.5751/ES-08723-210427

Grothmann T, Reusswig F (2006) People at risk of flooding: Why some residents take precautionary action while others do not. Nat Hazards 38:101-120. https://doi.org/10.1007/s11069-005-8604-6

Hagemeier-Klose M, Wagner K (2009) Evaluation of flood hazard maps in print and web mapping services as information tools in flood risk communication. Nat Hazards Earth Syst Sci 9:563-574. https://doi. org/10.5194/nhess-9-563-2009

Harries T (2008) Feeling secure or being secure? Why it can seem better not to protect yourself against a natural hazard. Health Risk Soc 10:479-490. https://doi.org/10.1080/13698570802381162

Hogan Carr R, Montz B, Maxfield K et al (2016) Effectively communicating risk and uncertainty to the public: assessing the national weather service's flood forecast and warning tools. Bull Am Meteorol Soc 97:1649-1665. https://doi.org/10.1175/BAMS-D-14-00248.1

Hopkins J, Warburton J (2015) Local perception of infrequent, extreme upland flash flooding: Prisoners of experience? Disasters 39:546-569. https://doi.org/10.1111/disa.12120

Kindon SL, Pain R, Kesby M (eds) (2007) Participatory action research approaches and methods: connecting people, participation and place. Routledge, New York

Knigge L, Cope M (2006) Grounded visualization: integrating the analysis of qualitative and quantitative data through grounded theory and visualization. Environ Plan A 38:2021-2037. https://doi.org/10. 1068/a37327

Lamond JE, Joseph RD, Proverbs DG (2015) An exploration of factors affecting the long term psychological impact and deterioration of mental health in flooded households. Environ Res 140:325-334. https://doi. org/10.1016/j.envres.2015.04.008

Landström C, Whatmore SJ, Lane SN et al (2011) Coproducing flood risk knowledge: redistributing expertise in critical 'participatory modelling'. Environ Plan A 43:1617-1633. https://doi.org/10.1068/ a43482

Lane SN (2012) Ethical risk management, but without risk communication? In: Kearnes M, Klauser FR, Lane SN (eds) Critical risk research practices, politics, and ethics. Wiley, Hoboken

Lane SN, Odoni N, Landström C et al (2011) Doing flood risk science differently: an experiment in radical scientific method. Trans Inst Br Geogr 36:15-36. https://doi.org/10.1111/j.1475-5661.2010.00410.x

Leedal D, Weerts AH, Smith PJ, Beven KJ (2012) A data based mechanistic real-time flood forecasting module for NFFS FEWS. Hydrol Earth Syst Sci Discuss 9:7271-7296. https://doi.org/10.5194/hessd-97271-2012

Marsh T, Kirby C, Muchan K et al (2016) The winter floods of 2015/2016 in the UK-a review. Centre for Ecology and Hydrology, Wallingford 
McBain W [Main author], Wilkes D, Retter M, Construction Industry Research and Information Association (2010) Flood resilience and resistance for critical infrastructure. CIRIA, London

Mees H, Crabbé A, Alexander M et al (2016) Coproducing flood risk management through citizen involvement: insights from cross-country comparison in Europe. Ecol Soc. https://doi.org/10.5751/ES08500-210307

Meyer V, Kuhlicke C, Luther J et al (2012) Recommendations for the user-specific enhancement of flood maps. Nat Hazards Earth Syst Sci 12:1701-1716. https://doi.org/10.5194/nhess-12-1701-2012

Milojevic A, Armstrong B, Wilkinson P (2017) Mental health impacts of flooding: a controlled interrupted time series analysis of prescribing data in England. J Epidemiol Community Health 71:970-973. https://doi.org/10.1136/jech-2017-208899

Munro A, Kovats RS, Rubin GJ et al (2017) Effect of evacuation and displacement on the association between flooding and mental health outcomes: a cross-sectional analysis of UK survey data. Lancet Planet Health 1:e134-e141. https://doi.org/10.1016/S2542-5196(17)30047-5

O'Sullivan JJ, Bradford RA, Bonaiuto M et al (2012) Enhancing flood resilience through improved risk communications. Nat Hazards Earth Syst Sci 12:2271-2282. https://doi.org/10.5194/nhess-12-22712012

Oliver K (2016) Flooding: a resident's view of Saturday 5th December. Corbridge Matters

Pain R (2004) Social geography: participatory research. Prog Hum Geogr 28:652-663

Paton D, Johnston D (2001) Disasters and communities: vulnerability, resilience and preparedness. Disaster Prev Manag Int J 10:270-277. https://doi.org/10.1108/EUM0000000005930

Paton D, Johnston DM (2006) Disaster resilience: an integrated approach. Charles C Thomas Publisher, New York

Rogers RW (1975) The protection motivation theory of fear appeals and attitude change. J Psychol 91:93-114

Slovic P, Kunreuther H, White GF (1974) Decision processes, rationality and adjustment to natural hazards. Earthscan Publications, London

Terpstra T (2011) Emotions, trust, and perceived risk: affective and cognitive routes to flood preparedness behavior: affective and cognitive routes to flood preparedness behavior. Risk Anal 31:1658-1675. https://doi.org/10.1111/j.1539-6924.2011.01616.x

Terpstra T, Gutteling JM (2008) Households' perceived responsibilities in flood risk management in the Netherlands. Int J Water Resour Dev 24:555-565. https://doi.org/10.1080/07900620801923385

Twigger-Ross C, Coates T, Orr P et al (2011) Community resilience research: final report on theoretical research and analysis of case studies report to the Cabinet Office and Defence Science and Technology Laboratory. Collingwood Environmental Planning Ltd, London

Twigger-Ross C, Kashefi E, Weldon S et al (2014) Flood resilience community pathfinder evaluation rapid evidence assessment. Defra, London

United States Geological Survey (2016) Flood inundation mapping (FIM) program. https://water.usgs.gov/ osw/flood_inundation/. Accessed 12 Apr 2017

Van Alphen J, Martini F, Loat R et al (2009) Flood risk mapping in Europe, experiences and best practices. J Flood Risk Manag 2:285-292. https://doi.org/10.1111/j.1753-318X.2009.01045.x

Wachinger G, Renn O, Begg C, Kuhlicke C (2013) The risk perception paradox-implications for governance and communication of natural hazards: the risk perception paradox. Risk Anal 33:1049-1065. https:// doi.org/10.1111/j.1539-6924.2012.01942.x

Waite TD, Chaintarli K, Beck CR et al (2017) The English national cohort study of flooding and health: cross-sectional analysis of mental health outcomes at year one. BMC Public Health 17:129. https://doi. org/10.1186/s12889-016-4000-2

Whitman GP, Pain R, Milledge DG (2015) Going with the flow? Using participatory action research in physical geography. Prog Phys Geogr. https://doi.org/10.1177/0309133315589707

Willis KF, Natalier K, Revie M (2011) Understanding risk, choice and amenity in an urban area at risk of flooding. Hous Stud 26:225-239. https://doi.org/10.1080/02673037.2011.549215 